\title{
RARE-EARTH ELEMENTS IN THE ARCHEAN IRON FORMATION AND ASSOCIATED SCHISTS IN UKKOLAN- VAARA, ILOMANTSI, SE FINLAND
}

\author{
KAUKO LAAJOKI and SEPPO LAVIKAINEN
}

\begin{abstract}
LAAJOKI, KAUKO and LAVIKAINEN, SEPPO 1977: Rare-earth elements in the Archean iron formation and associated schists in Ukkolanvaara, Ilomantsi, SE Finland. Bull. Geol. Soc. Finland 49 (2): $105-123$

This study describes the La, Ce, Nd, Sm, Eu, Tb, Yb and Lu concentrations in six iron-formation rocks $\left(\mathrm{Fe}_{\text {tot }} \gg 15 \%\right.$ ), four ferriferous schists $\left(\mathrm{Fe}_{\mathrm{tot}} \sim 10-15 \%\right.$ ) and two schist interbeds of the Archean Ukkolanvaara iron formation, as well as in seven associated schists of the Ilomantsi Schist Belt. For the same elements, two samples were analysed from the Archean Siivikkovaara iron formation in Kuhmo, one sample from the Archean Otravaara pyrite ore and one sample from the Karhusaari pyrite ore, probably Middle Precambrian in age.
\end{abstract}

All the iron-formation samples and the Otravaara pyrite ore show a marked positive Eu anomaly compared with the composite of North American shale (NAS) and are relatively poor in rare-earth elements (REE). The REE concentrations in the Ilomantsi schists are largely similar to those in the Sheba greywackes from the analogous ironformation-Dearing association of the Archean Fig Tree Group, South Africa. The ferriferous schists show a marked positive Eu anomaly compared with the NAS, but contain the other REE in as high abundances as the Ilomantsi schists on average.

The results confirm the general Eu excess in the Archean iron formations compared with younger iron-rich metasediments. The REE concentrations in the Archean schists characterized by an Eu excess in relation to younger pelitic schists are considered indicative of their general immaturity and a source area dominantly graniticgranodioritic in composition.

Kauko Laajoki and Seppo Lavikainen, Geological Survey of Finland, Kivimiehentie 1, SF-02150 Espoo 15, Finland.

\section{Introduction}

This paper is the direct sequel to a study concerning rare-earth element (REE) distribution in Finnish Precambrian (Karelian) iron formations (Laajoki 1975). Of the small Prekarelidic (Early Precambrian or Archean) iron-formation occurrences in East Finland, that of Ukkolanvaara in the parish of Ilomantsi (Fig. 1) was chosen as the study target because of the detail in which its geology is known. For this thanks are due to the Petrological Department of the Geological Survey of Finland (Lavikainen 1973 and 1977), who recently mapped the area. The purpose of the present paper is twofold: to give REE 


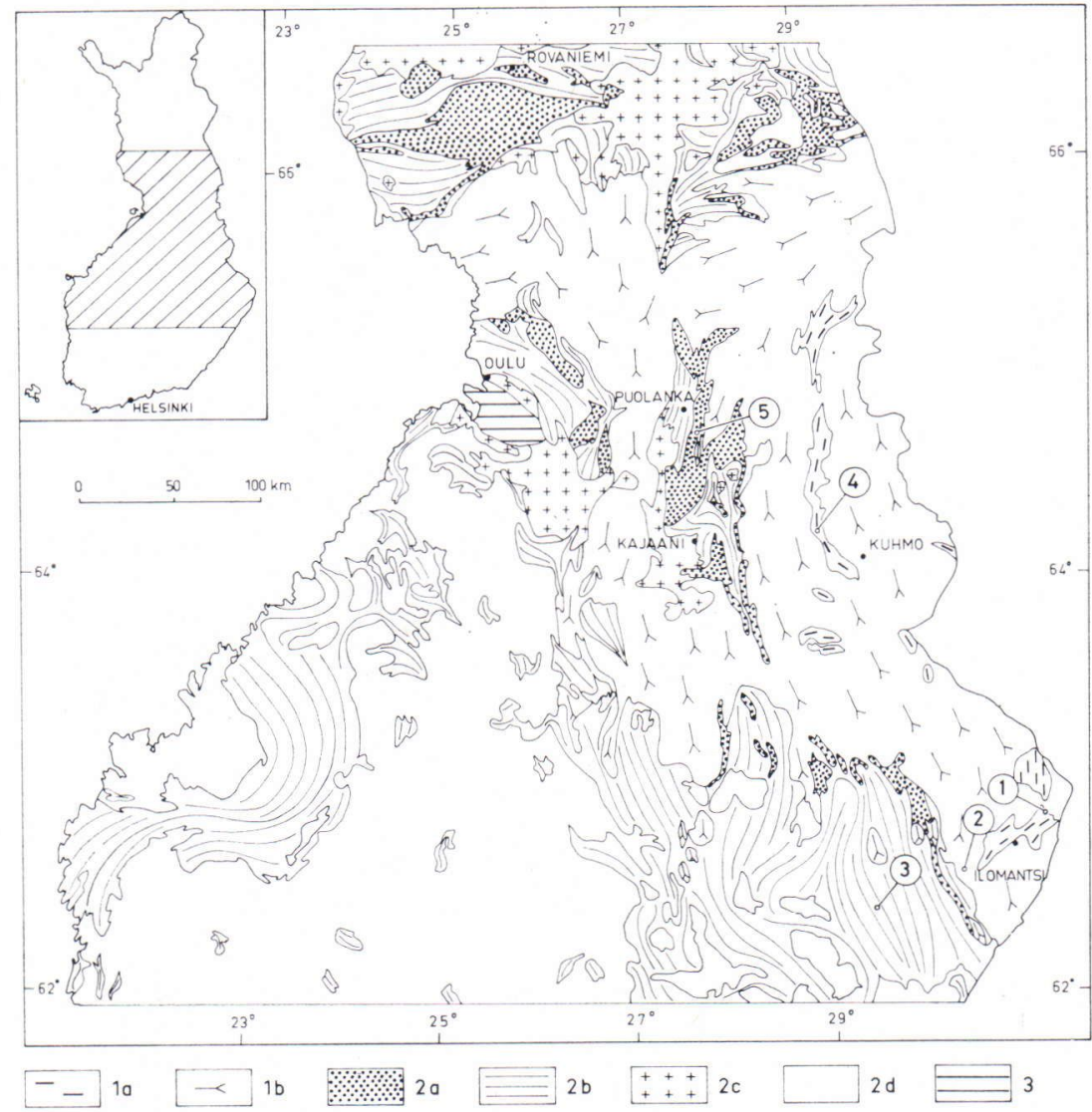

Fig. 1. The sites of the Ukkolanvaara iron formation (1), the Otravaara pyrite occurrence (2), the Karhunsaari pyrite occurrence (3), the Siivikkovaara iron formation (4), and the Väyrylänkylä iron formations (5) plotted on the simplified geological map of Finland (Simonen 1960). 1) Prekarelidic basement: a) schists and paragneisses, b) granite gneiss (orthogneisses). 2) Karelidic and Svecofennidic rocks: a) Karelian (Jatulian) quartzites, b) Karelidic and Svecofennidic schists, gneisses, migmatites, metabasalts and amphibolites, c) Karelidic granite, d) other (mainly silica-rich) orogenic plutonic rocks. 3) Jotnian sedimentary rocks (siltstone).

data on the Ukkolanvaara iron formation and the associated metasediments, and to discuss their significance in the classification of Precambrian iron formations of Finland into different age and genetic groups. For comparison, two samples were analysed from the Siivikkovaara iron formations, one from the pyrite ore of Otravaara and one from Karhusaari. Seppo Lavikainen is responsible for the geological background to the Ilomantsi area, and Kauko Laajoki for the processing of the REE analyses and the manuscript itself.

\section{Experimental}

The REE analyses were performed in the Reactor laboratory of the Technical Research Centre of Finland. The instrumental activation technique used has been described elsewhere (Rosenberg and Wiik 1971, Rosenberg 
1972, Koljonen and Rosenberg 1974). The other elements given in Table 2 were analysed in the Chemistry Department of the Geological Survey of Finland.

\section{General geological settings}

The bedrock in Eastern Finland is composed mainly of Prekarelidic basement orthogneisses that vary in age from about $2500 \mathrm{Ma}$ to $2900 \mathrm{Ma}$ (Kouvo 1958, Asa 1971, Lavikainen 1977). Within the basement area minor Archean schist belts occur in the parishes of Ilomantsi, Kuhmo and Suomussalmi (Fig. 1).

In Ilomantsi, the schist sequence begins with basal conglomerate with clasts of orthogneiss (zircon age c. $2900 \mathrm{Ma}$ ) and metavolcanics in a matrix composed partly of syndepositional tuffitic material and partly of clastic material derived from the basement. The lower part of the supracrustal rock sequence consists of basic metavolcanics overlain by pelitic metasediments. The iron formations are met with in the upper part of the metasedimentary group. The schists are penetrated by orthogneisses whose zircon ages vary from $2750 \mathrm{Ma}$ to $2860 \mathrm{Ma}$. Thus, the sedimentation and extrusion of the rocks of the Ilomantsi Schists Belt took place between $2900 \mathrm{Ma}$ and $2750 \mathrm{Ma}$. The Archean geology of the area seems to have many features in common with that of the Vermilion district, Minnesota, where volcanism, sedimentation (including the Soudan Iron Formation), folding, metamorphism, igneous intrusion and, probably, faulting also took place over a period of 50 to $100 \mathrm{Ma}$, about $2700 \mathrm{Ma}$ ago (Sims 1976).

Although not economic, the most noteworthy iron formations in Ilomantsi are encountered at Ukkolanvaara, where minor iron formations occur in mica schists. The iron formations apparently belonged originally to a single horizon some tens of metres thick
(Fig. 2). Only the main, NNW-SSE trending formation, about $3 \mathrm{~km}$ long and called the Ukkolanvaara iron formation (UIF), is treated in this study. In the light of structural interpretations, which were hindered by the scarcity of outcrops, the UIF represents a flank of a syncline. The schists in Matosärkkä, west of the Ukkolanvaara occurrence, are mainly mica schists showing graded bedding. They contain ferriferous interbeds and amphibole porphyroblasts and are interpreted to represent western lateral gradation of the UIF (Fig. 3). The schists east of the UIF are met with in only a few outcrops. They are pale-coloured muscovite-chlorite schists, occasionally containing biotite. The iron formation itself contains interbeds of "normal» as well as ferriferous mica schists and black schists that vary in thickness from some decimetres to a few metres. Thus, the Ukkolanvaara iron formation occurs within a normal supracrustal rock sequence without intimate association with volcanic rocks. This feature distinguishes it from the Kuhmo iron formations, which, applying the general classification by Gross (1965), are the best representatives of the Algoma type in Finland. Even the typical associated rocks of the Superior type, quartzite and dolomite, which are distinctive elsewhere, e.g. in the Karelian iron formations in Väyrylänkylä (Laajoki and Saikkonen 1977), are lacking in Ukkolanvaara. Hence, the depositional environment of the Ukkolanvaara formation was between that of the Superior and Algoma types and the UIF resembles the iron-formations, mainly older than $2300 \mathrm{Ma}$, met with in clastic association in Southern Africa (Beukes 1973).

Lithologically, the UIF is characterized by white chert mesobands, 5 to $20 \mathrm{~cm}$ thick, that separate thicker and darker units consisting of different iron-mineral rocks (Fig. 4). Predominant is a yellowish brown nonquartzose grunerite (or cummingtonite) rock that is laminated and contains hornblende in addi- 


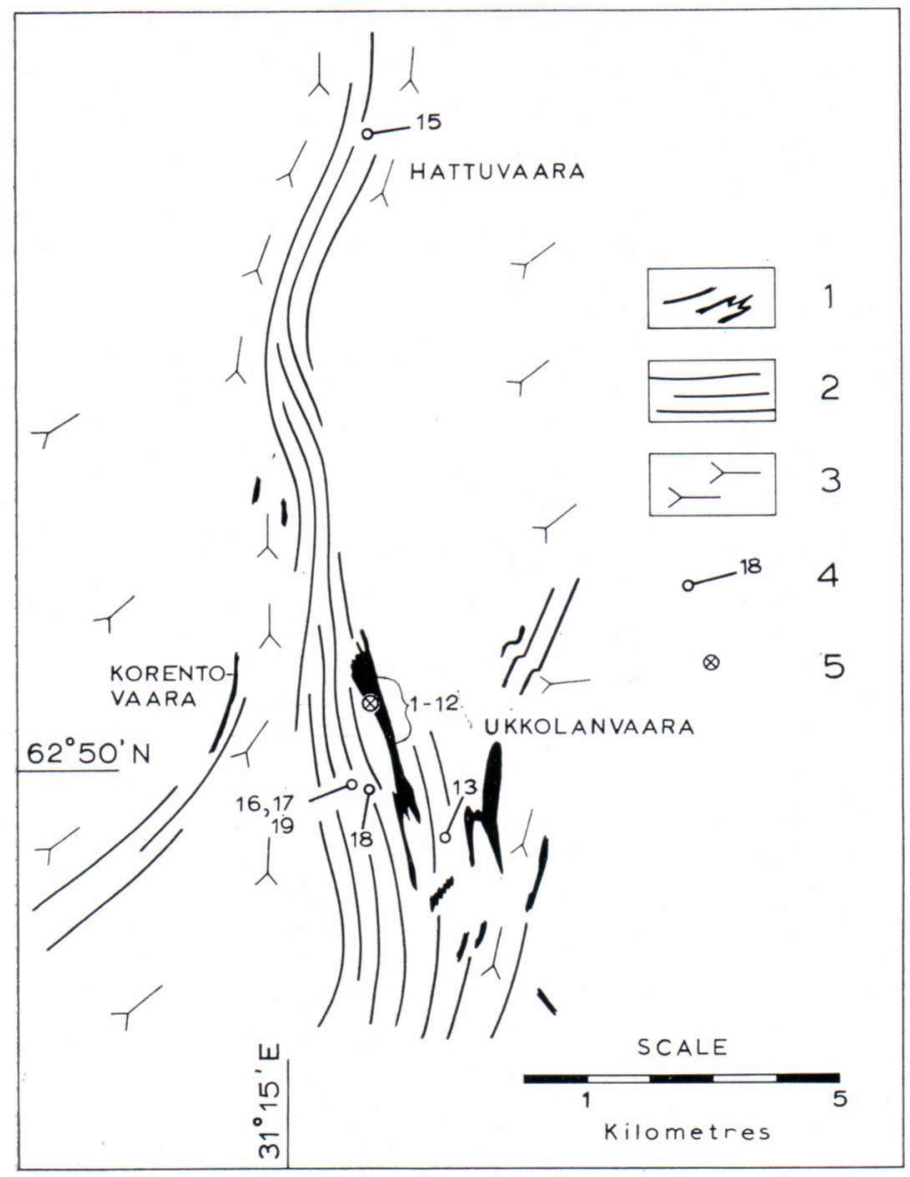

I
II $\leftarrow$

Fig. 2. Geological map of the Ukkolanvaara-Hattuvaara area (simplified from Lavikainen 1973). 1) Iron-formation occurrences (the thicknesses are exaggerated). 2) Schists. 3) Granodioritic basement orthogneisses. 4) Sampling site and sample number. 5) Drill hole.

Fig. 3. Stratigraphic columns from the different sections in the Ukkolanvaara area, Ilomantsi (Lavikainen 1977, Fig. 31). Sections: I = Korentovaara, II = Matosärkkä (position in Fig. 2 between Korentovaara and Ukkolanvaara), III = Ukkolanvaara, IV = Ilaja (east of Ukkolanvaara, beyond the map area in Fig. 2). Lithologic symbols: 1) Iron-formation rocks with pelitic schist interbeds. 2) Amphibole-bearing mica schist. 3) Black schist. 4) Mica schist. 5) Banded basic metavolcanics. 6) Massive metavolcanics and tremolite schist. 7) Gabbroidic basic metavolcanics. 8) Hornblende-chlorite schist. 9) Psammitic interbeds. 10) Conglomerate. 11) Gneissic granite. Numbers refer to Tables 1 and 2 .

\section{IV}

W

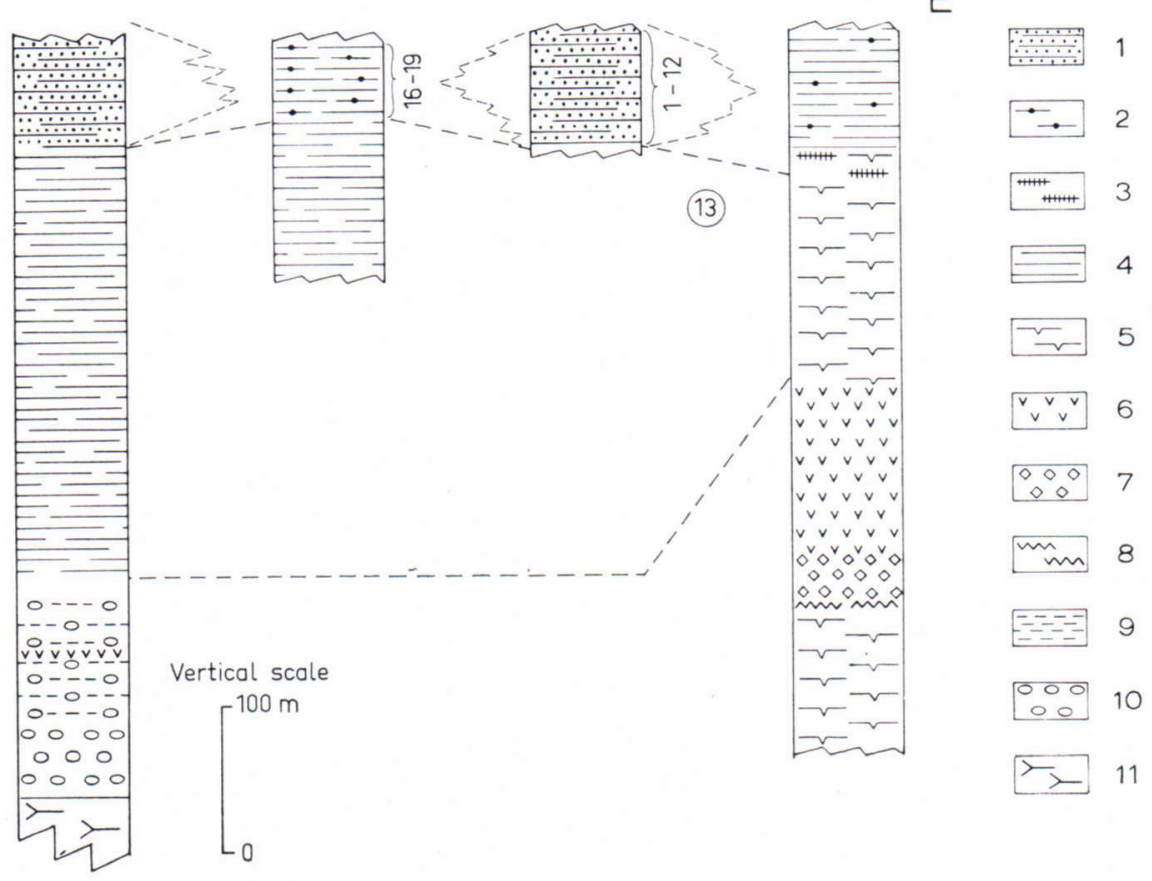


Fig. 4. Chert (white) and grunerite-magnetite mesobarids (grey, alternating with chert on the left) and two massive hornblende-garnet rock interbeds (on the right) in the UIF. The label measures $6 \times 6 \mathrm{~cm}$. Photo by $\mathrm{K}$. Laajoki.
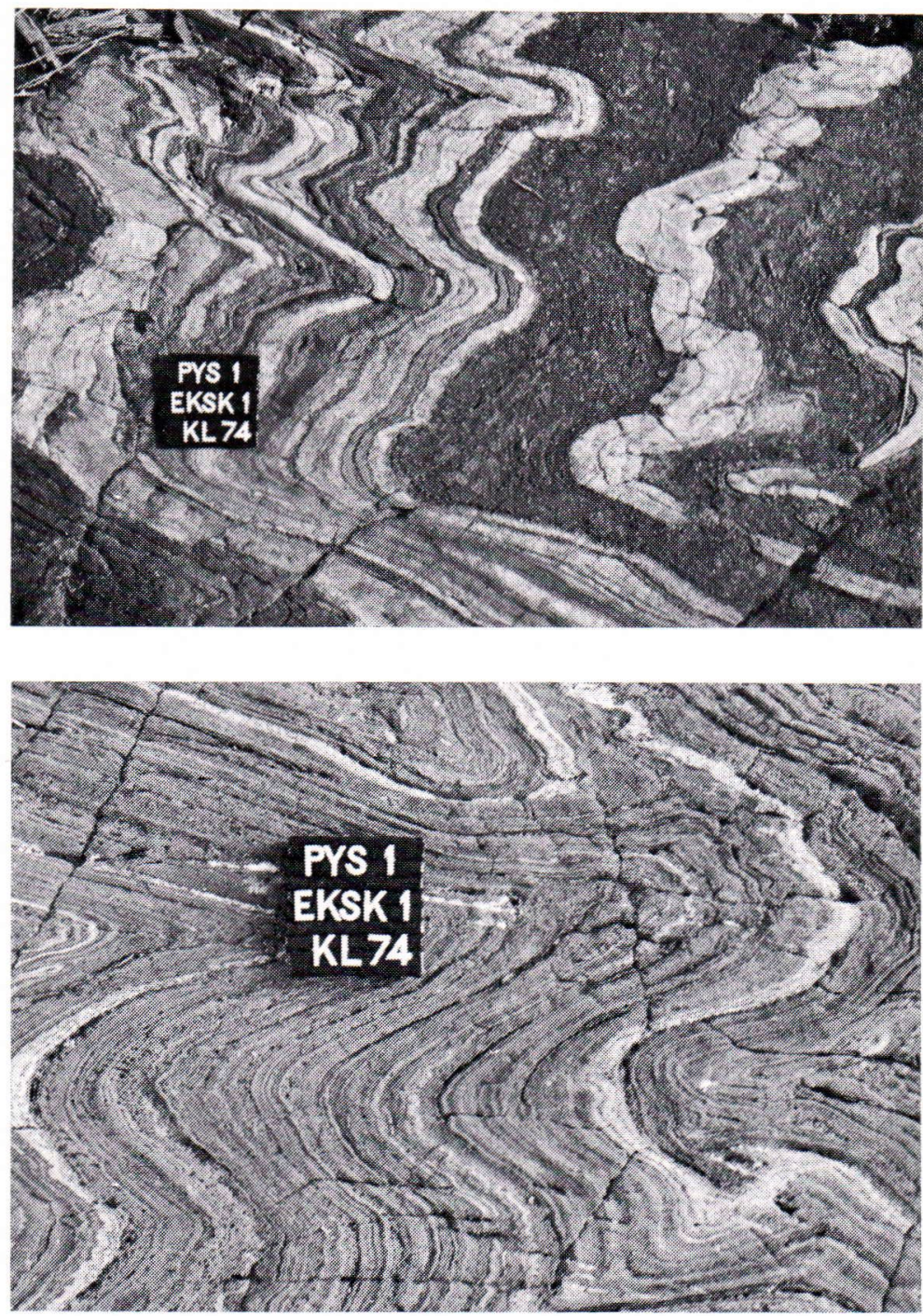

Fig. 5. Typical gruneritemagnetite-quartz-banded rock of the UIF. Photo by K. Laajoki.

the rock a striated appearence in black, yellowish brown and white (Fig. 5). In places, these three rock types are repeated in the following cyclical pattern: chert - gruneritemagnetite-quartz-banded rock - grunerite rock. Especially in the contact zones massive hornblende rock occurs in bands of a distinctive dark green colour. They often contain varying amounts of red garnet (diameter up to $2 \mathrm{~cm}$ ). Hornblende rocks are alternate with each other and impose upon 
also encountered as interbeds in the main parts of the formation (Fig. 4), where they often contain appreciable amounts of magnetite.

At the southwestern end of the Ilomantsi Schist Belt in Otravaara,, the sequence begins with basic metavolcanic rocks with minor iron formations (Saksela 1923, Nykänen 1971). The upper part is composed of leptites, mica schists, black schists, »ore quartzites», sericite schists and pyrite ores. The black schists and pyrite ores are closely associated with each other. The model age of the pyrite from Otravaara is 2400-2500 Ma (Wampler and Kulp 1964). Saksela (1923) explained the Otravaara pyrite ore (OPO) as formed by metasomatic processes produced by hydrothermal emanations from a granitic intrusion.

In Karhunsaari, the schist sequence begins with basal conglomerates and arkosites overlain by black schists, feldspar- and sericite-rich schists and biotite schists (Saksela 1933, Gillen and MacDonald 1971). The pyrite ore of Karhunsaari (KPO) occurs in the sericite schist, and Saksela (1933) correlated it genetically with the OPO. The extremely light sulphur isotopic composition (Kouvo 1958, p. 60), the low selenium content, and the physical relation to the black schist (Marmo 1960) suggest strongly that both the $\mathrm{KPO}$ and the OPO are of sedimentary origin as discussed by Wampler and Kulp (1964, p. 1433 and 1448). The $\mathrm{Pb}$ isotopic composition of the Karhunsaari pyrite indicates deposition of the ore more than $2100 \mathrm{Ma}$ ago (op. cit. p. 1448).

The schist belt of Kuhmo is composed mainly of basic metavolcanics with minor sericite quartzites and acid volcanics (Hyppönen 1973 and 1976). The rocks are penetrated by the Härmänjoki granodiorite, whose zircon age is $2740 \mathrm{Ma}$ (Geological Survey of Finland 1973). The iron formations of Silvikkovaara (SIF) occur as thin beds, 0.5 to $3 \mathrm{~m}$ thick, in meta-andesites (Papunen 1960).

\section{Sample description}

Table 1 lists the numbers, names and sampling locations of the samples analysed. All the samples from the iron-formation rocks $\left(\mathrm{Fe}_{\text {tot }} \gg 15 \%\right)$ of the UIF (Nos. 1-6) and the outcrop samples of the Ilomantsi metapelites were collected by Lavikainen, mainly during the mapping for the Ilomantsi map sheet in 1967. At the closing stage of the present study, the UIF was intersected by one drill hole (DH 1). The five samples (Nos. 7-11) collected from the drill core represent different pelitic schist interbeds. The sites of the samples from Ukkolanvaara and the neighbouring area are plotted on the simplified geologic map in Fig. 2. Their stratigraphic sites appear in Fig. 3.

Nos. 1 and 2 represent typical gruneritemagnetite-quartz-banded rock. Both samples were collected from the same band. The rock consists of roughly $1 \mathrm{~cm}$ thick mesobands, rich in grunerite and magnetite with some carbonate, and 1 to $2 \mathrm{~cm}$ thick quartz mesobands. Both mesoband types show microbanding. The former consist of discrete grunerite and magnetite laminae. The latter are composed almost solely of polygonal quartz. Of these samples, No. 1 is slightly weathered and contains some limonitic matter.

Nos. 3-6 represent nonquartzose silicaterich iron-formation rocks. Sample No. 3 is a weakly laminated rock that consists mainly of cummingtonite rimmed by green hornblende. Some carbonate is to be seen in the rock. No. 4 is a massive green hornblendemagnetite rock. Hornblende, which accounts for about $70 \%$ of the bulk of the rock, exhibits ample helicitic opaque (graphite) pigment.

Of the UIF samples analysed, No. 5 is unique in that it contains an abundance of garnet (almandine), biotite and chlorite in addition to hornblende. No. 6 is a massive 
Table 1. Rock stratigraphic positions, some petrological remarks and codes for samples from the Ukkolanvaara iron formation (UIF), pelitic metasediments from the Ilomantsi Schist Belt, two samples from the Siivikkovaara iron formation (SIF), and one sample from the Otravaara (OPO) and Karhunsaari pyrite ores (KPO).

\section{Sample number and name}

Grunerite-magnetite-quartz-banded rock

Cummingtonite rock

Hornblende-magnetite rock

5 Garnet-hornblende rock

6 Hornblende-grunerite rock

7 Hornblende-garnet schist

8 Garnet-hornblende-biotite schist

9 Garnet-biotite schist

10 Biotite schist

11 Biotite schist

12 Black schist

13 Muscovite-chlorite schist

14 Muscovite schist

15 Biotite schist

16 Coarse-grained part of a schist grade

17 Fine-grained part of a schist grade

18 Biotite schist

20 Quartz-amphibole-magnetite-banded rock

21 Magnetite-amphibole-banded rock

22 Pyrite ore

23 Quartz-banded pyrite ore

Rock-stratigraphic position

Remarks

Slightly weathered

Typical sample

$$
\begin{aligned}
& \text { middle part } \\
& \text { upper contact }
\end{aligned}
$$$$
\text { » upper part }
$$

$$
»
$$

ferriferous interbed

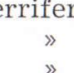

»

\section{» interbed}

"

Sonkaja, $30 \mathrm{~km} \mathrm{SW}$ of the UIF

Hattuvaara

West of UIF

$$
»
$$

》

$\mathrm{SIF}-2$

SIF - 1

OPO

$$
\text { » } \quad \text {, laminated }
$$

" , biotite- and

Typical sample, massive

Pigmented plagioclase

Relatively rich in apatite,

abundantly allanite inclusions

in biotite

Pigmented plagioclase

Abundant accessory epidote

Biotite-bearing

Biotite-rich

Pigmented plagioclase

Sulphide-bearing

Only traces of quartz, allanite-bearing

Slightly weathered
Sample code

$23 / 4244 / 74-\mathrm{SL}-67$

$50 / 》 / 74 \mathrm{~g}-\mathrm{SL}-67$

$26 / » / 145 \mathrm{~A}-\mathrm{STL}-73$

$27 /$ /66D-SL-67

28/ 》/R1-Gfos-74

$24 / \gg /$ A 283

$57 / » / \mathrm{DH} 1-78.40$

$59 / » / \mathrm{DH} 1-149.20$

$52 / \gg / \mathrm{DH} 1-32.45$

$53 / » / \mathrm{DH} 1-54.55$

$58 /$ »/DH 1-131.70

$46 / » / 75-\mathrm{SL}-67$

$29 / » / 54-\mathrm{SL}-67$

47/4242/15-68

$30 / 4333 / \mathrm{A} 221$

48/4244/A 278-1

$49 / \gg /$ A $278-2$

$54 / » / 53-\mathrm{SL}-67$

$25 /$ »/A 278-3

$22 / 4411 / 2-\mathrm{KL}-74$

$21 / 4411 / 1-\mathrm{KL}-74$

71/4241/KL-74-08-22

$70 / 4223 / \mathrm{KL}-75-08-26$ 
hornblende-grunerite rock with some magnetite. Petrographically, the rock resembles No. 4 , but it contains only minor magnetite and some grunerite.

Garnet(almandine)-bearing ferriferous $\left(\mathrm{Fe}_{\text {tot }}\right.$ $\sim 10-15 \%$ ) pelitic schists of the UIF are represented by Nos. $7-9$. No. 7 consists of bands, some of which are rich in green hornblende and quartz and some in biotite, chlorite, garnet and hornblende. In contrast to the other two samples, no feldspar has been detected in it. No. 8 is a biotite-rich schist characterized by bands rich both in biotite and plagioclase and other bands rich in quartz with some green hornblende, biotite and garnet. Both the plagioclase and the hornblende appear as porphyroblasts strongly pigmented by opaque (graphite) dust. No. 9 is a quartz-banded garnet-biotite schist with abundant plagioclase intensely pigmented by opaque (graphite).

No. 10, one of the ferriferous interbeds, is in some respects exeptional, being a mica schist that consists mainly of biotite, quartz, chlorite, and plagioclase. The biotite contains numerous small brownish inclusions with dark-coloured pleochroic haloes. According to microprobe determinations by J. Siivola, the inclusions are allanite. The feldspar of the rock occurs as roundish porphyroblasts that are almost completely saussuritized and pigmented by opaque (graphite). The relatively high $\mathrm{P}$ content of the rock (Table 2) is due to the unusually large amounts of apatite, an accessory that occurs as fairly sizeable grains whose centres have greyish hue imported by fine opaque dust. The REE content of apatite is too small to be detected by microprobe.

No. 11 is a biotite-schist interbed in the UIF with almost »normal» iron content. The rock consists mainly of biotite, plagioclase and quartz. The plagioclase is almost black under the microscope owing to the abundant opaque pigment, which microprobe studies reveal to be graphite. Pyrrhotite occurs as an accessory. No. 12 is a black schist containing quartz, sericite, chlorite, feldspar and pyrrhotite as main minerals, and apatite and rutile as accessories.

Nos. 13-19 represent typical metasediments with »normal» iron content $\left(\mathrm{Fe}_{\text {tot }} \ll\right.$ $10 \%$ outside the iron-formation horizon. Nos. 13 and 14 are feldspar-poor mica schists. The former is composed mainly of quartz, sericite and chlorite, and the latter of quartz, sericite and some biotite. Both rocks contain tourmaline and apatite as accessories. Sample No. 15 is a feldspar-bearing greywacke-like mica schist whose main minerals are quartz, biotite, K-feldspar, plagioclase and sericite. The accessories are epidote in abnormally large amounts, some carbonate, titanite, apatite, zircon and opaque.

Sample No. 16 was collected from the coarse-grained part and No. 17 from the fine-grained part of the same grade in a typical greywacke-like mica schist west of the UIF. The main components of both rocks are plagioclase, quartz and biotite, with the difference that No. 16 contains more plagioclase and less biotite than No. 17. The abundance of biotite in No. 17 is revealed geochemically by its high $\mathrm{TiO}_{2}$ content (Table 2). No. 18, which comes from an outcrop $100 \mathrm{~m}$ east of Nos. 16 and 17, is a feldsparbearing greywacke-like mica schist that contains both biotite and sericite. The biotite occurs as porphyroblasts, but the sericite is fine-grained. Sample No. 19 represents an $8 \mathrm{~cm}$ thick dark-coloured phyllitic interbed from the same outcrop from which Nos. 16 and 17 were collected. It is a feldspar-poor biotite schist that is distinguished from the other samples of »normal» metasediments by the abundant pigment of an opaque mineral similar to that in the feldspar of the ferriferous interbeds.

The SIF samples were collected by Laajoki from iron-formation beds separated from 
each other by a roughly $100 \mathrm{~m}$ thick metaandesite; No. 20 from the western end of the so-called »kiisumonttu» iron formation characterized by a poor sulphide dissemination (Papunen 1960, p. 35) and No. 21 from the major iron formation in Pahakangas, $120 \mathrm{~m}$ south of the first-named horizon. Of the samples, No. 20 is a thinly banded quartzamphibole rock with some magnetite and iron sulphides. Sample No. 21 comprises a magnetite-amphibole mesoband, $5 \mathrm{~cm}$ thick, and parts of two amphibole mesobands. Very few quartz grains are met with in the sample. The sample is exceptional among the Kuhmo samples in that it contains tiny grains of a yellow or brown mineral causing pleochroic haloes in the amphibole. According to the microprobe studies by J. Siivola, this mineral is allanite.

The pyrite ore sample from Otravaara was collected by Laajoki from a roadcut and is slightly weathered. The main ore mineral is pyrite with some marcasite. The sulphur content (Table 2) suggests that the sample contains $75 \% \mathrm{FeS}_{2}$. The other $25 \%$ is mainly quartz and amphibole. In the light of the microprobe analysis by $\mathrm{T}$. Paasivaara, the amphibole is tremolite (56 \% $\mathrm{SiO}_{2}, 0.03 \%$ $\mathrm{TiO}_{2}, 2.5 \% \mathrm{Al}_{2} \mathrm{O}_{3}, 2.8 \% \mathrm{FeO}, 0.6 \% \mathrm{MnO}$, $24 \% \mathrm{MgO}, 12.6 \% \mathrm{CaO}, 0.4 \% \mathrm{Na}_{2} \mathrm{O}, 0.1 \%$ $\mathrm{K}_{2} \mathrm{O}$ ). Furthermore, the rock contains fragments rich in sericite, amphibole, quartz and titanite. The Karhunsaari sample (No. 23) was collected by Laajoki from the adit at Suovaara (Saksela 1933, Fig. 12). The rock represents the quartz-banded type of the KPO and contains $48 \%$ pyrite and $49 \%$ quartz as shown by ore analysis (Table 2). The remaining $3 \%$ is chloritized biotite, sericite and an unidentified isotropic silicarich mineral.

\section{Results and discussion}

Table 2 gives the analytical data. REE contents normalized to the composite of 40 North American shales (NAS), mostly Paleozoic in age, (Haskin et al. 1968, Table 2), are presented graphically in Figs. 6-8. For general comparison (Figs. 9 and 10), some averages values were normalized to the composite of nine chondrites (op. cit., Table 1). Besides the REE listed in Table 2, Gd and Tm were also analysed in 10 samples. The mutual variations of these two elements were, however, so high and random that analyses were rejected.

REE in the iron-formation rocks of the UIF: All the iron-formation rocks show a clear depletion in the lighter REE and a marked positive Eu anomaly in comparison with the NAS (Fig. 6 A). No. 1, which represents a slightly weathered counterpart of No. 2, reveals a clear negative $\mathrm{Nd}$ anomaly. This is consistent with earlier observations on the effects of surface weathering on the REE distribution in iron-formation rocks (Laajoki 1975, p. 100). These two quartz (chert)-banded samples, which, in their low $\mathrm{Al}$ and $\mathrm{Ti}$ contents, are the purest chemical sediments among the UIF rocks, contain markedly less REE than do the nonquartzose iron-silicate-rich samples (Nos. 4-6). Of the latter, No. 5 is only slightly enriched in the lighter REE, probably owing to the abundant garnet in the rock.

$R E E$ in the ferriferous schist interbeds in the UIF: In comparison with the NAS, three (Nos. 7-9) of the four rocks analysed in this category show a sharp positive Eu anomaly, but are depleted in other elements by the factor $0.5-0.8$ (Fig. 6 B). The samples show an REE patterns, except Eu, very similar to that of some metapelites with normal iron content in Figs. $7 \mathrm{~A}$ and $\mathrm{B}$. This is also reflected in their average $\mathrm{REE}$ content which, except for the higher $\mathrm{Eu}$, is almost analogous to that of the Ilomantsi schists (Table 2, B and $\mathrm{F})$.

No. 10 is exceptionally rich in REE, espe- 
Table 2. REE concentrations (ppm) and contents of total iron, silica, $\mathrm{Al}_{2} \mathrm{O}_{3}, \mathrm{TiO}_{2}, \mathrm{P}_{2} \mathrm{O}_{5}$ and $\mathrm{S}$ (Wt-\%) and of $\mathrm{Cr}, \mathrm{Co}, \mathrm{Ni}(\mathrm{ppm})$ in the Ukkolanvaara and Silvikkovaara iron formations, in the pyrite ores of Otravaara and Karhunsaari, and in pelitic metasediments from the Ilomantsi Schist Belt. Sample

\begin{tabular}{|c|c|c|c|c|c|c|c|c|c|c|}
\hline No & $\mathrm{La}$ & $\mathrm{Ce}$ & $\mathrm{Nd}$ & $\mathrm{Sm}$ & $\mathrm{Eu}$ & $\mathrm{Tb}$ & $\mathrm{Yb}$ & $\mathrm{Lu}$ & $\Sigma$ REE' & $\mathrm{Eu}: \mathrm{Sm}$ \\
\hline 1 & 4.7 & 10.3 & $(0.68)$ & 1.3 & 0.56 & 0.26 & 0.97 & 0.21 & (18.98) & 0.43 \\
\hline 2 & 5.8 & 15.1 & 10.6 & 1.6 & 0.73 & $0.28 *$ & 1.4 & 0.26 & 35.77 & 0.46 \\
\hline 3 & 9.8 & 25.4 & 12.9 & 2.8 & 0.99 & 0.43 & 1.52 & 0.35 & 54.19 & 0.35 \\
\hline 4 & 9.2 & 26.2 & 13.3 & 3.0 & 1.68 & 0.53 & 1.99 & 0.37 & 56.27 & 0.56 \\
\hline 5 & 10.8 & 25.7 & 13.3 & 2.7 & 1.16 & 0.38 & $(0.23)$ & 0.27 & 54.54 & 0.43 \\
\hline 6 & 7.4 & 18.6 & 12.1 & 2.4 & 1.02 & 0.48 & 2.38 & 0.63 & 45.01 & 0.43 \\
\hline A & 9.3 & 24.0 & 12.9 & 2.7 & 1.21 & 0.46 & 1.96 & 0.41 & 52.50 & 0.44 \\
\hline 7 & 24 & 53 & 24 & 4.3 & 2.4 & 0.52 & 1.2 & 0.34 & 109.76 & 0.56 \\
\hline 8 & 18 & 50 & 20 & 3.9 & 1.8 & 0.56 & 2.0 & 0.41 & 96.67 & 0.46 \\
\hline 9 & 18.4 & 39.7 & 16.4 & 3.0 & 1.2 & 0.42 & 1.6 & $(<0.6)$ & $<81.32$ & 0.40 \\
\hline 3 & 20 & 48 & 20 & 3.7 & 1.8 & 0.50 & 1.6 & 0.38 & $\sim 95.9$ & 0.47 \\
\hline 10 & 135 & 317 & 124 & 18.0 & 5.5 & 1.8 & 3.7 & 0.41 & 605.41 & 0.31 \\
\hline 11 & 24 & 56 & 21 & 4.1 & 1.1 & 0.75 & 1.5 & 0.42 & 108.87 & 0.27 \\
\hline 12 & 17.2 & 41.5 & 20.2 & 3.4 & 0.96 & $0.45 *$ & 1.4 & 0.26 & 85.37 & 0.28 \\
\hline $\mathrm{C}$ & 20.6 & 48.8 & 20.6 & 3.8 & 1.0 & 0.60 & 1.5 & 0.34 & 97.12 & 0.27 \\
\hline 13 & 23.4 & 57.9 & 26.0 & 4.6 & 1.14 & 0.68 & 2.35 & 0.32 & 116.39 & 0.25 \\
\hline 14 & 19.8 & 47.2 & 19.8 & 4.1 & 1.02 & 0.56 * & 1.8 & 0.34 & 94.62 & 0.25 \\
\hline $\mathrm{D}$ & 21.6 & 52.3 & 22.9 & 4.4 & 1.08 & 0.62 & 2.08 & 0.33 & 105.51 & 0.25 \\
\hline 15 & 28.0 & 56.6 & 23.7 & 4.6 & 1.31 & 0.46 & 1.31 & 0.27 & 116.25 & 0.28 \\
\hline 16 & 8.9 & 24.8 & 9.9 & 2.4 & 0.75 & $0.35 *$ & 1.6 & 026 & 48.96 & 0.31 \\
\hline 17 & 13.1 & 34.5 & 15.4 & 3.2 & 0.94 & $0.47 *$ & 2.0 & 0.30 & 69.91 & 0.29 \\
\hline 18 & 14.5 & 45.4 & 17.4 & 4.1 & 1.1 & 0.80 & 2.7 & 0.28 & 86.28 & 0.27 \\
\hline 19 & 7.7 & 15.0 & 7.9 & 1.7 & 0.80 & 0.27 & 1.35 & 0.31 & 35.03 & 0.47 \\
\hline $\mathrm{E}$ & 11.1 & 29.9 & 12.7 & 2.3 & 0.90 & 0.47 & 1.91 & 0.29 & 60.05 & 0.34 \\
\hline$\vec{F}$ & 17.4 & 42.1 & 17.9 & 3.6 & 1.01 & 0.53 & 1.78 & 0.31 & 84.63 & 0.30 \\
\hline 20 & 3.3 & 8.0 & 3.3 & 1.2 & 0.82 & 0.27 & 0.86 & 0.19 & 17.94 & 0.68 \\
\hline 21 & 17.2 & 42.1 & 18.5 & 4.1 & 1.17 & 0.45 & 1.04 & 0.20 & 84.76 & 0.29 \\
\hline 22 & 2.0 & 3.7 & $<7$ & 0.53 & 0.25 & $<0.1$ & 0.25 & 0.06 & $<13.89$ & \\
\hline 23 & 0.5 & 0.8 & $<1.5$ & 0.12 & $<0.3$ & 0.04 & 0.12 & 0.03 & $<3.41$ & \\
\hline
\end{tabular}

*) estimated from the distribution pattern, y) analysed by optical-emission-spectrography, - = not determined. The values in brackets are not included in the calculated averages. $\Sigma \mathrm{REE}$ ' $=\mathrm{La}$, Ce, $\mathrm{Nb}$, $\mathrm{Sm}, \mathrm{Eu}, \mathrm{Tb}, \mathrm{Yb}, \mathrm{Lu}$.

cially in the lighter varieties. The total REE content is almost twice that of the phosphorite interband in the Pääkkö iron formation (Laajoki 1975, Table 2, No. 8). The Eu : Sm ratio in this sample is markedly lower than in other ferriferous schists. Because allanite is known to be enriched in the lighter REE and to contain only traces of $\mathrm{Eu}$ in relation to $\mathrm{Sm}$ (Lee and Bastron 1967), these exeptions are obviously due to the presence of abundant acessory allanite in the rock.

$R E E$ in the schist interbeds in the UIF: Both interbeds analysed, the biotite schist (No. 11) and the black schist (No. 12), show distribution patterns (Fig. $7 \mathrm{~A}$ ) and total contents similar to those of the muscovitechlorite schist east of the UIF and the Sonkaja muscovite schist (Fig. 7 B). 
descriptions are given in Table 1. REE analyses by Riitta Zilliacus and Rolf Rosenberg (Nos. 7, 8, 11, 22 and 23), Reactor Laboratory of the Technical Research Centre of Finland. The other elements were analysed in the Chemistry Department of the Geological Survey of Finland.

\begin{tabular}{|c|c|c|c|c|c|c|c|c|c|}
\hline La : Lu & $\mathrm{Fe}_{\text {tot }} \%$ & $\mathrm{SiO}_{2} \%$ & $\mathrm{Al}_{2} \mathrm{O}_{3} \quad \%$ & $\mathrm{TiO}_{2} \%$ & $\mathrm{P}_{2} \mathrm{O}_{5} \%$ & $\mathrm{~S} \%$ & $\left.\mathrm{Cr}^{\mathrm{y}}\right)$ & $\mathrm{Coy})$ & Niy) \\
\hline $\begin{array}{l}22.4 \\
22.3\end{array}$ & $\begin{array}{l}39.6 \\
40.1\end{array}$ & - & $\begin{array}{l}0.77 y) \\
0.85 y)\end{array}$ & $\begin{array}{l}0.03 \\
0.03\end{array}$ & $\begin{array}{l}0.41 \\
0.30\end{array}$ & $\begin{array}{l}0.17 \\
0.11\end{array}$ & $\begin{array}{l}170 \\
170\end{array}$ & $\begin{array}{l}<20 \\
<20\end{array}$ & $\begin{array}{l}<20 \\
<20\end{array}$ \\
\hline $\begin{array}{l}28.0 \\
24.9 \\
40.0 \\
11.7\end{array}$ & $\begin{array}{l}29.3 \\
29.3 \\
30.3 \\
21.8\end{array}$ & $\begin{array}{l}- \\
\overline{39.73}\end{array}$ & $\begin{array}{c}2.5 \\
7.6 \\
8.8 \\
14.44\end{array}$ & $\begin{array}{l}0.13 \\
0.28 \\
0.23 \\
0.51\end{array}$ & $\begin{array}{l}0.46 \\
0.60 \\
0.17 \\
0.24\end{array}$ & $\begin{array}{c}0.07 \\
0.29 \\
0.13 \\
-\end{array}$ & $\begin{array}{l}170 \\
220 \\
200 \\
220\end{array}$ & $\begin{array}{r}<20 \\
<20 \\
<20 \\
18\end{array}$ & $\begin{array}{r}23 \\
40 \\
27 \\
100\end{array}$ \\
\hline 26.1 & 27.7 & & 8.3 & 0.29 & 0.37 & 0.16 & 203 & $<20$ & 48 \\
\hline $\begin{aligned} & 70.6 \\
& 43.9 \\
(> & 31)\end{aligned}$ & $\begin{array}{l}15.8 \\
11.6 \\
10.6\end{array}$ & - & $\begin{array}{l}11.8 \\
17.4 \\
13.2\end{array}$ & $\begin{array}{l}0.55 \\
0.73 \\
0.55\end{array}$ & $\begin{array}{l}0.14 \\
0.25 \\
0.16\end{array}$ & $\begin{array}{l}0.19 \\
0.03 \\
0.81\end{array}$ & $\begin{array}{l}190 \\
210 \\
280\end{array}$ & $\begin{array}{l}<20 \\
<20 \\
<20\end{array}$ & $\begin{array}{l}92 \\
86 \\
96\end{array}$ \\
\hline 57.3 & 12.7 & & 14.1 & 0.61 & 0.18 & 0.34 & 227 & $<20$ & 91 \\
\hline 329 & 12.8 & - & 14.0 & 0.90 & 1.56 & 0.06 & 500 & 29 & 270 \\
\hline $\begin{array}{l}57.1 \\
66.2\end{array}$ & $\begin{array}{l}7.71 \\
7.75\end{array}$ & - & $\begin{array}{l}15.3 \\
13.8\end{array}$ & $\begin{array}{l}0.53 \\
0.47\end{array}$ & $\begin{array}{l}0.18 \\
0.40\end{array}$ & $\begin{array}{l}0.86 \\
2.44\end{array}$ & $\begin{array}{l}420 \\
270\end{array}$ & $\begin{array}{l}32 \\
34 \\
\end{array}$ & $\begin{array}{r}92 \\
110\end{array}$ \\
\hline 61.7 & 7.73 & & 14.6 & 0.50 & 0.29 & 1.65 & 345 & 33 & 101 \\
\hline $\begin{array}{l}73.1 \\
58.2\end{array}$ & $\begin{array}{l}6.01 \\
4.54\end{array}$ & $\overline{65.07}$ & $\begin{array}{l}17.0 \\
15.81\end{array}$ & $\begin{array}{l}0.78 \\
0.68\end{array}$ & $\begin{array}{l}0.41 \\
0.09\end{array}$ & $\begin{array}{c}0.08 \\
-\end{array}$ & $\begin{array}{l}330 \\
270\end{array}$ & $\begin{array}{r}<20 \\
28\end{array}$ & $\begin{array}{r}55 \\
140\end{array}$ \\
\hline 65.6 & 5.28 & & 16.4 & 0.73 & 0.25 & & 300 & & 98 \\
\hline 103.7 & 3.51 & 68.21 & 15.57 & 0.54 & 0.18 & - & 27 & 12 & 26 \\
\hline $\begin{array}{l}34.2 \\
43.7 \\
51.8 \\
24.8\end{array}$ & $\begin{array}{l}5.42 \\
6.87 \\
8.40 \\
5.36\end{array}$ & $\begin{array}{c}64.56 \\
55.27 \\
- \\
60.68\end{array}$ & $\begin{array}{c}1.4 .99 \\
18.71 \\
-. \\
17.41\end{array}$ & $\begin{array}{l}0.65 \\
1.09 \\
0.93 \\
0.79\end{array}$ & $\begin{array}{l}0.11 \\
0.13 \\
0.16 \\
0.18\end{array}$ & $\begin{array}{l}- \\
\overline{0.42} \\
0.03\end{array}$ & $\begin{array}{l}160 \\
290 \\
- \\
270\end{array}$ & $\begin{array}{l}31 \\
42 \\
11\end{array}$ & $\begin{array}{r}100 \\
150 \\
82\end{array}$ \\
\hline 38.6 & 6.51 & & & 0.87 & 0.16 & & & & \\
\hline 57.0 & 6.71 & & & 0.72 & 0.21 & & & & \\
\hline $\begin{array}{l}17.4 \\
86.0 \\
33.3 \\
16.7\end{array}$ & $\begin{array}{l}24.0 \\
37.2 \\
36.8 \\
23.4\end{array}$ & $\begin{array}{l}58.05 \\
33.98 \\
16.40 \\
49.25\end{array}$ & $\begin{array}{l}0.20 \\
0.74 \\
3.10 \\
0.49\end{array}$ & $\begin{array}{l}0.00 \\
0.02 \\
0.13 \\
0.05\end{array}$ & $\begin{array}{l}0.25 \\
0.18 \\
0.1 .1 \\
0.09\end{array}$ & $\begin{array}{l}1.67 \\
0.11 \\
40.4 \\
25.8\end{array}$ & $\begin{array}{r}<150 \\
230 \\
200 \\
130\end{array}$ & $\begin{array}{r}<20 \\
<20 \\
150 \\
180\end{array}$ & $\begin{array}{r}<20 \\
<20 \\
180 \\
320\end{array}$ \\
\hline
\end{tabular}

A) Av. of Nos. 3-6. B) Av. of Nos. 7-9. C) Av. of Nos. 11-12. D) Av. of Nos. 13-14. E) Av. of Nos. 16-19. F) Av. of Nos. 11-19.

REE in the Ilomantsi schists: On the basis of their REE contents and lithology, the schists with normal iron content can be divided into two main group. The first comprises two schists rich in muscovite and relatively rich in REE (Nos. 13 and 14). They reveal almost identical REE distribution patterns, and REE contents that are only slightly lower than those in the NAS (Fig.
7 B). The second group is composed of five biotite-rich samples. Of these, No. 15 is relatively rich in $\mathrm{REE}$ and in somewhat more enriched in the lighter REE than are the NAS (Fig. 7 C). This unusual feature is attributed to the abundant accessory epidote of the rock. The NAS normalized REE patterns of the other four (Nos. 16-19) are clearly depleted in the lighter REE. The rocks contain 


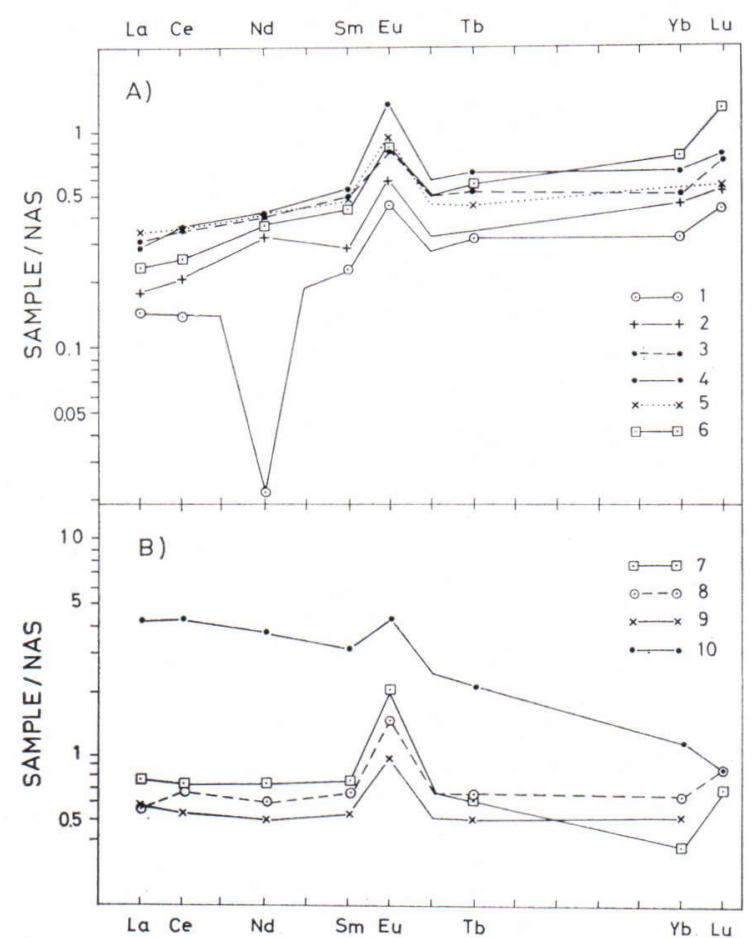

Fig. 6. NAS-normalized REE distribution patterns for the iron-formation rocks (A) and the ferriferous schist interbeds of the UIF (B).

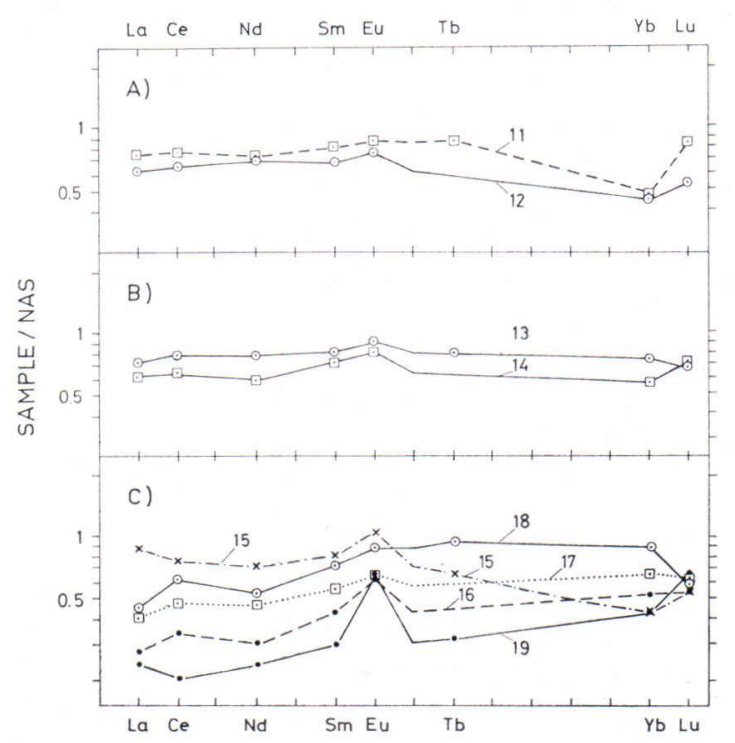

Fig. 7. NAS-normalized REE distribution patterns for the metapelite interbeds with normal iron content from the UIF (A), for the muscoviterich (B) and biotite-rich (C) metapelites from the Ilomantsi schist belt.

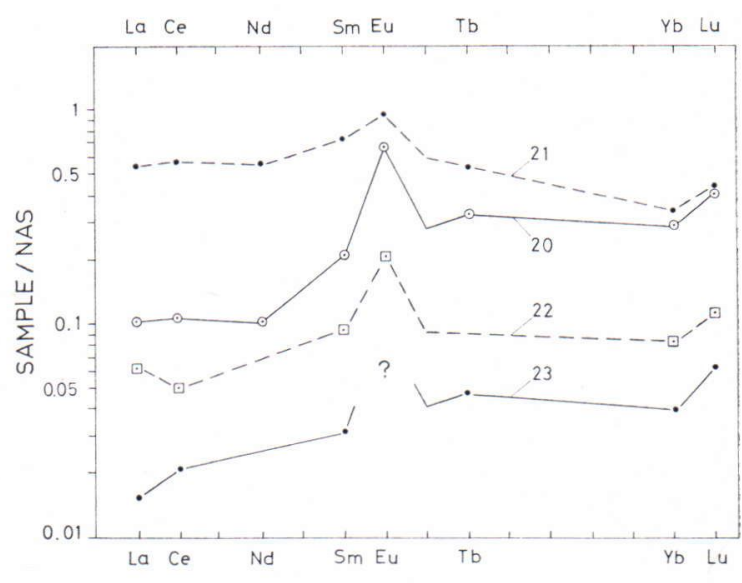

Fig. 8. NAS-normalized REE distribution patterns for the iron-formation rocks of the SIF (Nos. 20 and 21) and the pyrite ore samples of the OPO (No. 22) and KPO (No. 23),

markedly less REE than do the two muscovite-rich schists (Fig. 7 B).

It is of special interest to compare the relative $\mathrm{REE}$ distributions in the different parts of the graded bed analysed. The lower part, more rapidly deposited and relatively plagioclase-rich and biotite-poor (No. 16), contains less REE and shows a somewhat higher positive Eu anomaly t'ian does the upper part of the grade (No. 17). This is consistent with the conclusions drawn by Haskin et al. (1966, p. 269) that mafic rockforming minerals tend to have higher REE concentrations than do felsic minerals, whereas the latter exhibit a strong anomalous preference for Eu. No. 19 is exceptionally poor in REE and shows an NAS-normalized distribution pattern and a positive $\mathrm{Eu}$ anomaly similar to those in the iron-formation rocks of the UIF. It apparently represents an intercalation deposited during a very slow sedimentation period. Otherwise its chemistry is similar to that of other biotite-rich schists.

REE in the SIF samples: SIF sample No. 20 has a REE distribution pattern (Fig. 8) and an absolute REE content identical to the 
Härmänjoki sample analysed earlier from Kuhmo (Laajoki 1975, No. 20). No. 21 differs drastically from these two in that it contains about five times more REE in total and has an Eu:Sm ratio even lower (0.29) than that in Middle Precambrian iron formations of Superior type in general $(0.31-0.43$, Laajoki 1975, Table 3). Moreover, it is not depleted in the lighter REE (Fig. 8). This peculiarity, as in No. 10 , is attributed to the presence of allanite.

$R E E$ in the OPO and KPO samples: The OPO sample (No. 22) closely resembles the quartz-banded types of the UIF (Nos. 1 and 2). This similarity suggests that the Otravaara pyrite ore represents a sulphide facies of iron formation. The KPO sample contains the lowest absolute REE content found so far in iron-rich rocks in Finland. Its REE content is as low as that in the massive magnetite and hematite reported by Fryer (1977, Nos. 25 and 27) from the Archean (?) iron formation in Mary River. This very low absolute REE content can be attributed to the insignificant silicate and phosphate contents of the rock as revealed by the low $\mathrm{Al}_{2} \mathrm{O}_{3}, \mathrm{TiO}_{2}$ and $\mathrm{P}_{2} \mathrm{O}_{5}$ values in Table 2.

$\mathrm{Cr}$, Co and $\mathrm{Ni}$ content: These trace elements were analysed in the hope of gaining information about the possible volcanic affinities of each deposition. In spite of their contrasting lithologic association, the UIF and SIF samples show almost identical $\mathrm{Cr}$, Co and $\mathrm{Ni}$ contents, of which $\mathrm{Co}$ and $\mathrm{Ni}$ are mostly below detection limits. The $\mathrm{Ni}$ in the UIF samples bears a clear positive correlation to $\mathrm{TiO}_{2}$ (Table 2, Nos. 1-6). The $\mathrm{Cr}$ content is about twice that in the Karelian ironformation rocks in Väyrylänkylä (Laajoki and Saikkonen 1977, Table 14). Of the metapelite samples, No. 10 is the richest in $\mathrm{Cr}$ and Ni. The Co content is, however, normal. No. 15 is exceptionally poor in all three elements. The upper relatively biotite-rich part of the grade (No. 17) contains markedly more $\mathrm{Cr}$, $\mathrm{Co}$ and $\mathrm{Ni}$ than the lower, more felsic part (No. 16). Both the OPO and KPO samples are comparatively rich in $\mathrm{Co}$ and $\mathrm{Ni}$.

General discussion: The nonquartzose silicate iron-formation rocks in Ukkolanvaara (SUIF) are relatively richer in REE than are the Kuhmo and other Archean iron formations (Balashov and Goryainov 1966, Fryer 1977). The absolute REE abundance in the quartzose variety (Nos. 2) is close to that in the massive magnetite and banded magnetitehematite iron formation of Mary River (Fryer 1977, Nos. 24 and 28). There is, however, no depletion in Ce.

Table 3 gives some REE parametres for the Precambrian iron formations in Finland. The Kuhmo occurrences (excluding the allanitebearing SIF-1) are characterized by a low $\mathrm{REE}$ content and a high $\mathrm{Eu}: \mathrm{Sm}$ ratio, the UIF by a markedly higher REE content and a lower Eu : Sm ratio, and the Väyrylänkylä occurrences by low Eu : Sm and high La : Lu rations. The pyrite ores of Karhunsaari and Otravaara seem to be very poor in REE. All these differences may be related to the specific sedimentation environment of each occurrence as revealed by the associated rocks and by some faint but specific lithochemical features. Thus, of iron formations in Finland, those at Kuhmo are, in terms of $\mathrm{Al}_{2} \mathrm{O}_{3}$ and $\mathrm{TiO}_{2}$, the chemical sediments poorest in these elements (Laajoki and Saikkonen 1977, Fig. 73 a). The UIF is composed mainly of iron-silicate-rich rocks and, like the other Archean iron formations in North Karelia (op. cit. Fig. 73 a), is relatively rich in $\mathrm{Al}_{2} \mathrm{O}_{3}$. The Väyrylänkylä iron formations are exceptionally rich in phosphorus. Both pyrite ores differ from the typical sulphide facies described by James (1954) in that they are noncarbonaceous and relatively poor in $\mathrm{Al}_{2} \mathrm{O}_{3}$ and $\mathrm{TiO}_{2}$. This difference is also revealed by distinctly higher REE abun- 
Table 3. REE characteristics of the Finnish Precambrian iron formations proper and one quartz-banded hematite ore from Sweden. Averages are weighted for the number of analysis.

\begin{tabular}{|c|c|c|c|c|c|c|c|c|}
\hline Occurrence & $\begin{array}{l}\text { Age } \\
\text { (Ma) }\end{array}$ & Associated rocks & $\begin{array}{l}\text { Iron-formation } \\
\text { facies }\end{array}$ & Anal. & $\underset{(\mathrm{ppm})}{\sum \mathrm{REE}} *$ & $\mathrm{Eu}: \mathrm{Sm}$ & $\mathrm{La}: \mathrm{Lu}$ & References \\
\hline \multirow[t]{2}{*}{$\begin{array}{l}\text { Kuhmo } \\
\text { Härmänjoki } \\
\text { Siivikkovaara-2 }\end{array}$} & \multirow[t]{2}{*}{$>\underset{》}{2740}$} & \multirow[t]{2}{*}{$\begin{array}{c}\text { Basic metavolcanics } \\
»\end{array}$} & \multirow[t]{2}{*}{$\underset{»}{\text { Mixed oxide-silicate }}$} & $\begin{array}{l}1 \\
1\end{array}$ & $\begin{array}{l}16 \\
18\end{array}$ & $\begin{array}{l}0.63 \\
0.68\end{array}$ & $\begin{array}{l}26 \\
17\end{array}$ & \multirow[t]{2}{*}{$\begin{array}{l}\text { Laajoki } 1975 \text {, Table } 2, \text { No. } 20 \\
\text { This study, Table } 2 \text {, No. } 20\end{array}$} \\
\hline & & & & 2 & 17 & 0.66 & 22 & \\
\hline Siivikkovaara-1 & $»$ & » & $»$ & 1 & 85 & 0.29 & 86 & No. 21 \\
\hline $\begin{array}{l}\text { Ilomantsi } \\
\text { Ukkolanvaara } \\
\text { » }\end{array}$ & $\begin{array}{l}\geq 2750 \\
<2900\end{array}$ & Mica schists & Noncherty silicate \pm & $\begin{array}{l}1 \\
4\end{array}$ & $\begin{array}{l}36 \\
53\end{array}$ & $\begin{array}{l}0.46 \\
0.44\end{array}$ & $\begin{array}{l}22 \\
26\end{array}$ & $\begin{array}{ll}》 & \text { No. } 2 \\
》 & \mathrm{~A}\end{array}$ \\
\hline & & & oxide & 5 & 49 & 0.44 & 25 & . \\
\hline Otravaara & $>2600$ & $\begin{array}{l}\text { Basic metavolcanics, } \\
\text { quartz-feldspar } \\
\text { schists, black schists }\end{array}$ & Sulphide & 1 & $<14$ & 0.47 & 33 & » No. 22 \\
\hline $\begin{array}{l}\text { Puolanka } \\
\text { Väyrylänkylä }\end{array}$ & 2080 & $\begin{array}{l}\text { Quartzite-phyllite- } \\
\text { dolomite-black schist }\end{array}$ & $\begin{array}{l}\text { Mixed oxide-silicate } \\
\text { Carbonate }\end{array}$ & $\begin{array}{l}4 \\
1\end{array}$ & $\begin{array}{l}63 \\
53\end{array}$ & $\begin{array}{l}0.31 \\
0.24\end{array}$ & $\begin{array}{l}59 \\
92\end{array}$ & 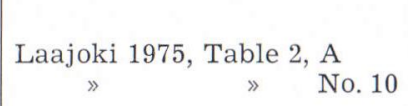 \\
\hline Karhunsaari & $\begin{array}{l}\gtrsim 2100 \\
<2600\end{array}$ & $\begin{array}{l}\text { Feldspar } \pm \text { sericite } \\
\text { schists, black schists }\end{array}$ & $\begin{array}{l}\text { Noncherty Fe-sili- } \\
\text { cate interbands } \\
\text { Sulphide }\end{array}$ & $2^{5}$ & 41 & $\begin{array}{r}0.30 \\
0.28\end{array}$ & 25 & 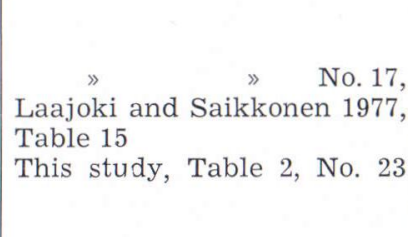 \\
\hline $\begin{array}{l}\text { Central Sweden } \\
\text { Kallmorberg }\end{array}$ & $\sim 1800$ ? & $\begin{array}{l}\text { Acid metavolcanics } \\
\text { (leptites) }\end{array}$ & Oxide (hematite) & 1 & 35 & 0.63 & $\sim 50$ & $\begin{array}{l}\text { Holmqvist } 1971 \text {, Table } 7: 13 \text {, } \\
\text { composite of quartz-banded } \\
\text { hematite ore. }\end{array}$ \\
\hline
\end{tabular}


dances in the carbonaceous sulphide-facies rocks (Wildemand and Haskin 1973, No. 9, Laajoki 1975 Nos. 12 and 13).

The occurrences mentioned do not exhibit any distinct secular changes in REE. Fortunately, there are two rock groups with almost similar lithology and bulk chemistry, namely, the garnet-bearing iron-silicate interbands of the Pääkkö iron formation and the nonquartzose silicate-rich rocks of the UIF. Interestingly the chondrite normalized REE patterns of the former show a negative $\mathrm{Eu}$ anomaly, whereas the latter show a positive Eu anomaly (Fig. 9). The REE data available in the literature and discussed recently by Fryer (1977) indicate that the Archean iron formations (age $\lesssim 2500 \mathrm{Ma}$ ) have $\mathrm{Eu}: \mathrm{Sm}$ rations from about 0.40 to 1.22 , whereas the same ratio in the Middle Precambrian and younger banded iron formations varies from about 0.40 to 0.24 , which is close to that in the Mesozoic massive Mn deposit in the Apennines (0.27, Bonati et al. 1976b), the Mesozoic Cyprus ochres and umbers (0.240.30, Robertson and Fleet 1976) and the Pacific metalliferous sediments $(0.28-0.36$, Dymon et al. 1973). The same trend is to be seen when the REE pattern of the OPO sample is compared with that of the pyrite concretion in the Romanche Trench (Fig. 9). However, the quartz-banded hematite ore of Kallmorberg (KQHO), probably Middle Precambrian in age, has as high an $\mathrm{Eu}: \mathrm{Sm}$ ratio as the Archean Kuhmo iron formations on average (Table 3 ). The Ordovician oxide ironformations associated with the massive sulphide ores in New Brunswick, SW Canada, show unusually high and variable $\mathrm{Eu}: \mathrm{Sm}$ ratios (0.27-10.10; av. 2.63, Graf 1977). As discussed by Graf (op.cit.), the $\mathrm{Eu}$ : Sm ratio appears to be the higher the greater the $\mathrm{Pb}$ content of the sample, this marked exception to the general secular trend may be related to the presence of small quantities of galena in the New Brunswick iron formations.

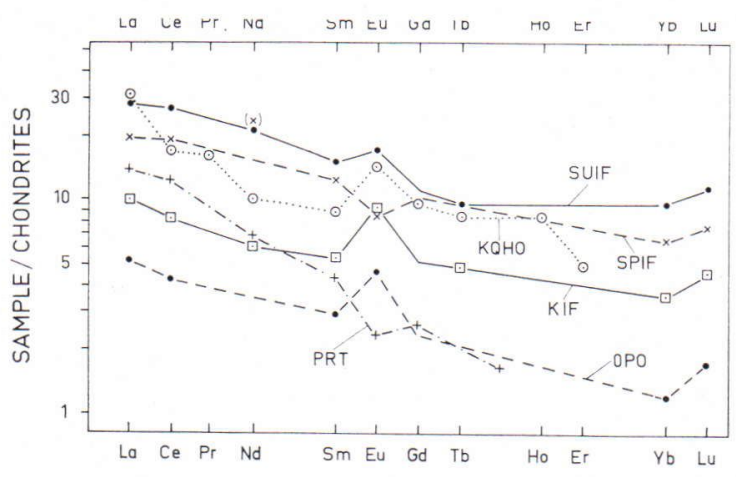

Fig. 9. Chondrite-normalized REE distribution patterns for the average silicate-rich rocks of the UIF (=SUIF, Table 2, A), the average of two noncherty garnet-bearing iron-silicate interbands from Pääkkö (=SPIF, Laajoki 1975, Table 2, No. 17, Laajoki and Saikkonen 1977, Table 15), for the composite of 15 samples of Kallmorberg quartzbanded hematite ore $(=\mathrm{KQHO}$, Holmqvist 1971, Table $7: 13$ ), for the average of two Kuhmo iron formations (=KIF, Table 2, No. 20, Laajoki 1975, Table 2, No. 20), for the OPO sample (Table 2, No. 22 ) and the pyrite concretion from the Romanche Trench (= PRT, Bonatti et al. 1976a, Table 2).

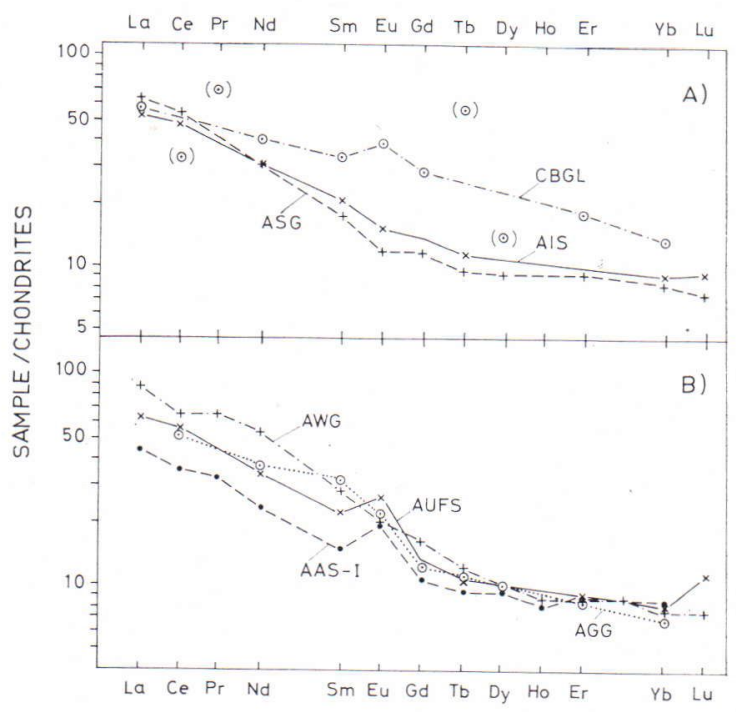

Fig. 10. Chondrite-normalized REE distribution patterns for some Archean rocks. CBGL = composite of 40 gneissic granites and granite gneisses from Finnish Lapland (Sahama 1945, Table 28). AIS $=$ average of 9 Ilomantsi schists (this study, Table 2, F). ASG = average of 6 Sheba greywackes (Wildeman and Condie 1973, Table 2). AWG = average of 6 Wyoming greywackes (op. cit., Table 1). AUFS $=$ average of 3 ferriferous metapelites of the UIF (this study, Table 2, B). AAS-I = average of 6 Kalgoorlie sedimentary rocks (Nance and Taylor 1977, Table 4). AGG = average of 10 granitic and granodioritic (ortho)gneisses from Godthåb (O'Nions and Pankhurst 1974, Table 2). 
Fig. 10A shows the average chondritenormalized REE pattern for the Archean Ilomantsi schists (AIS) compared with that of the Archean Sheba greywackes of the Fig Tree Group. Both rocks can be considered as representatives of the first type of clastic association described by Beukes (1973, p. 1000). The rocks show similar REE patterns consistent with their apparent analogous sedimentation environment and age. As to the Finnish rocks, the AIS and the Karelian Tohmajärvi and Kangasala greywackes (Wildeman and Haskin 1973) are not marked by a depletion in $\mathrm{Eu}$, compared with chondrites, whereas the Karelian Outokumpu black schist (op. cit.) and the Karelian metapelites in Puolanka (Laajoki 1975 and 10 unpublished analyses) show a clear negative $\mathrm{Eu}$ anomaly, in relation to chondrites. Thus, in Finland, there seems to be no abrupt change in $\mathrm{Eu}$ content between the Prekarelian and Karelian clastic sediments.

It should be noted, however, that the ferriferous metapelites of the UIF show $\mathrm{Eu}$ : Sm ratios as large as those in the iron-formation rocks themselves and have an average REE distribution pattern similar to that in Archean Australian schists (Fig. 10 B). Moreover, there is no linear correlation between the $\mathrm{Eu}: \mathrm{Sm}$ ratio and the total iron contents in the Ilomantsi metasediments, but the $\mathrm{Eu}: \mathrm{Sm}$ ratio falls abruptly from about 0.47 to 0.30 when the total iron content decreases to below 10 per cent (Fig. 11). The ferriferous schists as well as the iron-formation rocks obviously contain some chemical sedimentary components which absorbed selectively $\mathrm{Eu}$ from the sea water or, as discussed by Fryer (1977), the chemical sediments reflect the original $\mathrm{Eu}$ enrichment in the Archean sea water. There are, however, two exceptions to this rule: No. 10, whose low $\mathrm{Eu}: \mathrm{Sm}$ ratio and REE pattern are due to the presence of allanite and were evidently produced in a meta-

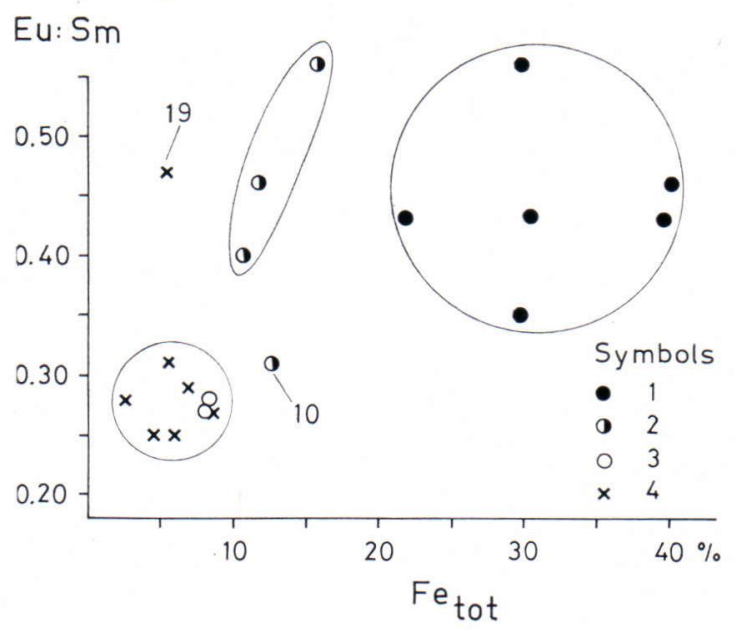

Fig. 11. Eu : Sm/Fetot plot of the Ilomantsi metasediments (Nos. 1-19 in Table 2). 1) Iron-formation rocks of the UIF. 2) Ferriferous interbeds of the UIF. 3) Metapelite interbeds of the UIF. 4) "normal» metapelites of the Ilomantsi Schist Belt.

morphic system, and No. 19. The reason why No. 19 is so exceptional has not been established with certainity.

Nance and Taylor (1977) have shown that positive Eu enrichments attributed to local accumulation of feldspar during sedimentation could also have been formed in Paleozoic rocks. They suspect that the enrichment of $\mathrm{Eu}$, in relation to chondrites, observed in the Archean sedimentary rocks probably has the same cause. They further discussed that »there is no reason to suppose that such an enrichment has wider significance, implying an excess Eu content, relative to chondrites, as a general feature of Archean crust, exposed to weathering" (op.cit., p. 228). However, if the REE data available for both the clastic and chemical sediments are taken into consideration, the general $\mathrm{Eu}$ excess in Archean sediments seems to be a significant and regional phenomenon. This, coupled with the secular variation of the $\mathrm{K}_{2} \mathrm{O}: \mathrm{Na}_{2} \mathrm{O}$ ratio in sedimentary rocks (Engel et al. 1974), and with the re- 
sults of the oxygen isotope study of Archean clastic metasedimentary rocks from Canada (Longstaffe and Schwarcz 1977), suggests that the excess is simply due to the general immature nature (Pettijohn 1943) of the Archean sediments.

As can be seen in Fig. 10, the Ilomantsi, Sheba, Wyoming and Australian schists and the Archean granitic and granodioritic gneisses from Godthåb have fairly similar REE patterns. Further the REE pattern for the composite of basement gneisses from Finnish Lapland does not deviate much from the average for the Ilomantsi schists. On the basis of their REE distribution, the Ilomantsi schists could thus have derived from a source area dominantly granitic-granodioritic in composition. This is in logical agreement with their geologic evolution discussed in the introductory chapter. In principle, this explanation is analogous to the bimodal tholeiticfelsic igneous suite proposed by Nance and Taylor (1977) as a probable source of the Archean sedimentary rocks.

\section{Concluding remarks}

1) $\mathrm{Nd}$ is leached out by Preglacial weathering processes more easily than the other REE.
2) The low REE concentrations in Otravaara and Karhunsaari pyrite ores suggest that they are of chemical sedimentary origin.

3) The REE in the Ukkolanvaara iron formation confirms the general Eu excess in the Archean iron formations in relation to younger iron-rich chemical sediments.

4) The presence of some REE-bearing accessory minerals gives rise to anomalous REE concentrations and distribution patterns in the rock.

5) The REE concentrations in the Archean rocks of mechanical sedimentary origin seem to reflect a crust dominantly granitic-granodioritic in composition.

Acknowledgements - The authors are indebted to Mrs. Riitta Zilliacus and Dr. Rolf Rosenberg of the Technical Research Centre of Finland for the REE analyses, to all those in the Chemistry Department who performed supplementary chemical analyses, to Miss Tuula Paasivirta and Dr. Jaakko Siivola for microprobe determinations, to Mrs. Rauha Tapanainen, Mrs. Marjo-Riitta Kujala-Tammi, Mrs. Elsa Järvimäki and Mrs. Anni Vuori for drawing the figures. The English of the manuscript was corrected by Mrs. Gillian Häkli.

\section{References}

Asa, M. (1971) Radiometrisiä iänmäärityksiä Kainuusta. [Radiometric age determinations from Kainuu]. Master's thesis, Dep. Geol., Univ. Helsinki.

Balashov, Yu. A. and Goryainov, P. M. (1966) Rare earth elements in the Precambrian iron-bearing rocks of the Imandra Region. Geochem. Int. $3(2): 240-251$.

Beukes, N. J. (1973) Precambrian iron-formations of southern Africa. Econ. Geol. 68(7): 9601004 .

Bonatti, E., Honnorez-Guerstein, M. B., Honnorez,
J. and Stern, C. (1976a) Hydrothermal pyrite concretions from the Romanche Trench (Equatorial Atlantic): Metallogenesis in oceanic fracture zones. Earth and Planetary Sci. Lett. 32(1): $1-10$.

Bonatti, E., Zerbi, M., Kay, R. and Rydell, H. (1976b) Metalliferous deposits from the Apennine ophiolites: Mesozoic equivalent of modern deposits from oceanic spreading centers. Geol. Soc. Am. Bull. 87(1): 83-94.

Dymond, J., Corliss, J. B., Heath, G. R., Field, C. W., Dasch, E. J. and Veeh, H. H. (1973) 
Origin of metalliferous sediments from the Pacific Ocean. Geol. Soc. Am. Bull. 84(10): $3355-3372$.

Engel, A. E. J., Itson, S. P., Engel, C. G., Stickney, D. M. and Cray, E. J. (1974) Crustal evolution and global tectonics: a petrogenic view. Bull. Geol. Soc. Am. 85(6): 843-858.

Fryer, B. J. (1977) Rare earth evidence in ironformations for changing Precambrian oxidation states. Geochim. Cosmochim. Acta 41(3): 361367.

Geological Survey of Finland (1973) Annual report on the activities for the year 1972 (in Finnish with an English summary), 59 p.

Gillen, C. and MacDonald, J. G. (1971) Report on expedition to Finland. Univ. Glasgow Expl. Soc. $28 \mathrm{p}$.

Graf, J. L., Jr. (1977) Rare earth elements as hydrothermal tracers during the formation of massive sulfide deposits in volcanic rocks. Econ. Geol. 72(4): 527-548.

Gross, G. A. (1965) Geology of iron deposits in Canada. Vol. I, General geology and evaluation of iron deposits. Geol. Surv. Can., Econ. Geol. Rep. No. 22. 181 p.

Haskin, L. A., Frey, F. A., Schmitt, R. A. and Smith, R. H. (1966) Meteoritic, solar and terrestrial rare-earth distribution. Pp 169-321 in Physics and Chemistry of the Earth, vol. 7, ed. by L. H. Ahrens, F. Press, S. K. Runcorn and H. C. Urey. Pergamon Press. Oxford.

Haskin, L. A., Haskin, M. A., Frey, F. A. and Wildeman, T. R. (1968) Relative and absolute terrestrial abundances of the rare earths. Pp. 889-912 in Origin and distribution of the Elements ed. by L. H. Ahrens, Pergamon Press. Oxford.

Holmqvist, A. (1971) Relationerna mellan kvartsrandmalm, skarnmalm, skarn- och skölbildning. Exempel från Kallmorbergsgruvan, Norberg. Mineral. Avdel. Geol. Inst., Stockholm Univ.

Hyppönen, V. (1973) [Pre-Quaternary rocks], 4412 Hiisijärvi. Geological Map of Finland, $1: 100000$.

- (1976) [Pre-Quaternary rocks], 4411 Ontojoki. Geological Map of Finland, 1: 100000.

James, H. L. (1954) Sedimentary facies of iron formation. Econ. Geol. 49(3): 235-293.

Koljonen, T. and Rosenberg, R. J. (1974) Rare earth elements in granitic rocks. Lithos 7(4): $249-261$.
Kouvo, O. (1958) Radioactive age of some Finnish Precambrian minerals. Comm. Géol. Finland. Bull. 182. 70 p.

Laajoki, K. (1975) Rare-earth elements in Precambrian iron formations in Väyrylänkylä, South Puolanka area, Finland. Bull. Geol. Soc. Finland 47: 93-107.

Laajoki, K. and Saikkonen, R. (1977) On the geology and geochemistry of the Precambrian iron formations in Väyrylänkylä, South Puolanka area, Finland. Bull. Geol. Surv. Finland 292. $137 \mathrm{p}$.

Lavikainen, S. (1973) [Pre-Quaternary rocks], 4244 Ilomantsi. Geological Map of Finland, $1: 100000$.

- (1977) Ilomantsin Ukkolanvaaran alueen kallioperän synnyn ja kehityksen tulkintaa [On interpretation of the origin and evolution of the bedrock in the Ukkolanvaara area, Ilomantsi]. Ph. licentiate's thesis. Dep. Geol., Univ. Turku.

Lee, D. E. and Bastron, H. (1967) Fractionation of rare-earth elements in allanite and monazite as related to geology of the Mt. Wheeler mine area, Nevada. Geochim. Cosmochim. Acta 31 (3): $339-356$.

Longstaffe, F. J. and Schwarcz, H. P. (1977) ${ }^{18} 0 / 160$ of Archean clastic metasedimentary rocks: a petrogenetic indicator for Archean gneisses? Geochim. Cosmochim. Acta 41 (9): $1303-1312$.

Marmo, V. (1960) On the sulphide and sulphidegraphite schists of Finland. Bull. Comm. Géol. Finland 190. $80 \mathrm{p}$.

Nance, W. B. and Taylor, S. R. (1977) Rare earth element patterns and crustal evolution - II. Archean sedimentary rocks from Kalgoorlie, Australia. Geochim. Cosmochim. Acta 41(2): $225-231$.

Nykänen, O. (1971) Kallioperäkartan selitys, 4241 Kiihtelysvaara. English summary: Explanation to the map of rocks. Geological Map of Finland, $1: 100000.68 \mathrm{p}$.

O'Nions, R. K. and Pankhurst, R. J. (1974) Rareearth element distribution in Archean gneisses and anorthosites, Godthåb area, West Greenland. Earth and Planetary Sci. Lett. 22(4): $328-338$.

Papunen, H. (1960) Havaintoja Siivikkovaaran alueen kallioperästä Kuhmon pitäjän Vieksinkylässä. [Observations on the bedrock in the Siivikkovaara area, Vieksinkylä, Kuhmo]. Master's thesis. Dep. Geol. Univ. Helsinki. 
Pettijohn, F. J. (1943) Archean sedimentation. Geol. Soc. Am. Bull. 54(7): 925-972.

Robertson, A. H. F. and Fleet, A. J. (1976) The origins of rare earths in metalliferous sediments of the Troodos Massif, Cyprus. Earth and Planetary Sci. Lett. 28(3): 385-394.

Rosenberg, R. J. (1972) Instrumental activation analysis of Lunar samples. Suomen kemistilehti B 45: 399-404.

Rosenberg, R. J. and Wiik, H. B. (1971) Instrumental activation analysis of 11 lanthanide elements in Apollo 12 Lunar samples. Radiochim. Radioanal. Lett. 6, 45.

Sahama, Th. G. (1945) Spurenelemente der Gesteine im südlichen Finnish-Lappland. Bull. Comm. Géol. Finland 135. 86 p.

Saksela (Saxen) M. (1923) Über die Petrologie des Otravaaragebietes im östlichen Finnland. Bull. Comm. Géol. Finland 65. 63 p.

Saksela, M. (1933) Die Kieserzlagerstätte von Kar- hunsaari in Nordkarelien, Finnland. Geol. Fören. Stockholm Förhandl. 55(1): 29-58.

Simonen, A. (1960) Pre-Quaternary rocks in Finland. Bull. Comm. Géol. Finland 191. 49 p.

Sims, P. K. (1976) Early Precambrian tectonicigneous evolution in the Vermilion district, northeastern Minnesota. Geol. Soc. Am. Bull. 87 (3): $379-389$.

Wampler, J. M. and Kulp, J. L. (1964) An isotopic study of lead in sedimentary pyrite. Geochim. Cosmochim. Acta 28 (9): 1419-1458.

Wildeman, T. R. and Condie, K. C. (1973) Rare earths in Archean graywackes from Wyoming and from the Fig Tree Group, South Africa. Geochim Cosmochim. Acta 37(3): 439-453.

Wildeman, T. R. and Haskin, L. A. (1973) Rare earths in Precambrian sediments. Geochim. Cosmochim. Acta 37(3): 419-438.

Manuscript received May 25, 1977. 